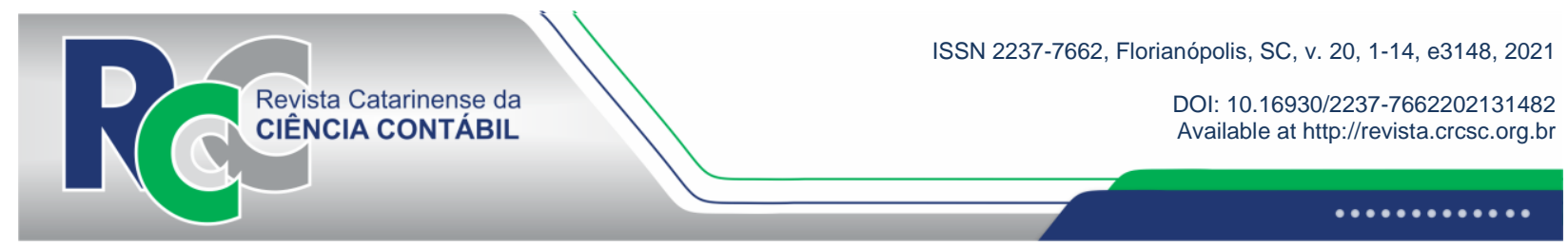

\title{
COST STICKINESS IN THE LOCAL GOVERNMENTS OF SANTA CATARINA
}

\author{
MARIANA CAMPAGNONI \\ Federal Rural University of Rio de Janeiro \\ Address: BR 465, Km 07 | Zona Rural | 23890-000 | \\ Seropédica/RJ | Brazil. \\ (1) https://orcid.org/0000-0001-6069-2385 \\ marianacampagnoni@ufrrj.br
}

VALKYRIE VIEIRA FABRE

Santa Catarina State University

Address: Rua Dr. Getúlio Vargas, 2822 | Bela Vista | 89140-

OOO Ibirama/SC | Brasil.

(1) https://orcid.org/0000-0002-4664-1415

valkyrie.fabre@udesc.br

\author{
ALTAIR BORGERT \\ Federal University of Santa Catarina \\ Address: Campus Universitário, CSE/CCN | Trindade | \\ 88040-900 | Florianópolis/SC | Brazil. \\ (D) https://orcid.org/0000-0002-0116-8089 \\ altair@borgert.com.br
}

\author{
SULIANI ROVER \\ Federal University of Santa Catarina \\ Address: Campus Universitário, CSE/CCN | Trindade | \\ 88040-900 | Florianópolis/SC | Brazil. \\ (1) https://orcid.org/0000-0001-8612-2938 \\ suliani.rover@ufsc.br
}

\begin{abstract}
Asymmetric cost behavior took a new approach, starting in 2003, with the emergence of the Cost Stickiness Theory (CST) and, since it is something recent, there are still doubts regarding its application in the public sector. In this sense, this study aims to analyze the behavior of costs in local governments in Santa Catarina, from the cost stickiness perspective. This is an empirical, quantitative, and documentary study that uses the population of 295 municipalities in Santa Catarina during the 20-year period, whose transposition of the analysis model was adapted for the public sector. We grouped the costs in blocks, with the proposition of nine regression models with panel data, of which, eight corroborate the cost stickiness phenomenon. Still, the results indicate similarity with the flypaper phenomenon, typical of the public sector, which uses part of the recipe to calculate the asymmetry, in which of the three types of analyzes performed, the use of the recipe is linked to the one that resulted in the highest sticky. Finally, it offers subsidies for the application of CST to the public sector, even in the case of a typical phenomenon of forprofit entities, and concludes that, with the use of fractional revenue (as well as in the phenomenal flypaper) for local governments of Santa Catarina, the behavior of costs appears to be stickier.
\end{abstract}

Keywords: Cost behavior. Cost stickiness. Asymmetry of costs. Public costs. Local government.

Edited in Portuguese and English. Original version in English.

Received on 2/4/2021. Revised on 5/19/2021. Accepted on 5/25/2021 by Prof. Dr. Sérgio Murilo Petri (Editor-in-Chief) and Prof. Dr. Sandro Vieira Soares (Associated Editor). Published on 6/25/2021.

Copyright () 2021 RCCC. All rights are reserved. It is allowed to quote part of articles without prior authorization, provided the source is identified. 


\section{INTRODUCTION}

The government practice of limiting public expenditures to revenues resulted in the literary consolidation of the balanced budget in the mid-1850s, which remains in the literature and legal rules governing public accounts today (Santos, Ribeiro, Ribeiro \& Pinto, 2017). However, the scarcity of resources has worried managers and researchers, and led to the improvement of procedures and theories regarding the issues involving costs. In 1937, the Theory of the Firm, by economist Ronald Coase, started a new dimension in management research, with consequences in procedures and cost methods, mostly directed to the private sector, focused on profit maximization.

Traditionally, in studies on cost behavior, the assumption is the symmetrical behavior of costs regarding revenues, that is, revenues and costs increase or decrease in the same proportion, while the asymmetrical behavior occurs when there is not the same proportion. However, the discussions have expanded with theoretical and empirical contributions on the subject to such an extent that, today, cost asymmetry is already recognized in the literature and has given rise to the newest accounting theory on cost behavior, the Cost Stickiness Theory (CST), based on the seminal work of Anderson, Banker, and Janakiraman (2003), who offered a mathematical explanation for the phenomenon.

CST assumes that costs normally increase when productive activities increase, but do not decrease to the same extent when productive activities decrease and uses revenues and total cost (including expenses) as the calculation basis. In Brazil, the model received important contributions, especially from Richartz and Borgert (2020). However, this theory is still in an international consolidation phase.

In the public sphere, the costs issue has gained prominence in recent decades, but there are several research gaps linked to the sector's peculiarities (Bracci, Humphrey, Moll, \& Steccolini, 2015; Helden \& Uddin, 2016), one of which is related to the behavior of public costs. In general, studies on CST use business samples from for-profit entities. However, Hosomi and Nagasawa (2018) state that it cannot be applied to the pure public sector, due to the non-profit nature of governments. Thus, the CST literature is still particularly incipient for the public sector, and the cost stickiness phenomenon still lacks adequacy to public accounts.

For the CST purposes, business costs are considered in their entirety. However, for this study's purposes, which adapts the behavioral model to the public sector, all executed budget expenditures are considered costs. In this sense, successive periods of balanced budgets (measured by the result for the period) presuppose symmetrical behavior (measured by the variation between periods) in the cost behavior. Although most countries establish the obligation of a balanced budget in the public sector by using the public finances balancing as a precept, there are indications that this does not always occur, which casts doubt on the supposed symmetrical behavior.

Indirectly, research reveals non-proportional variations in public expenditure given increases or decreases in revenues, for example, in studies on the flypaper effect (Gamkhar \& Oates, 1996; Volden, 1999; Kandil, 2001; Levaggi \& Zanolla, 2003; Lago-Peñas, 2008; Sakurai, 2013; Gennari \& Messina, 2014), which measures whether local public expenditures are equally sensitive to increases in intergovernmental transfers and personal income (Levaggi \& Zanolla, 2003; Lago-Peñas, 2008; Gennari \& Messina, 2014). Although flypaper behavior measures specific public accounts symmetry or asymmetry, it concurrently opens up the possibility that CST is also applicable to the public sector, as according to the model proposed by Anderson et al. (2003), non-proportional variations in costs are expected due to an increase or decrease in revenues.

We can see this evidence in the work of Lago-Peñas (2008), in which financial and political factors explain the differentiated behavior of expenditures as election periods approach. 
Furthermore, party ideologies or the tax collection level can determine the way accounts are managed and, consequently, the variation between income and expenses. For Sakurai (2013), if the economy is booming, domestic production increases and tax collection grows, however, in economic recession times, reducing expenses is not so simple, because public needs remain growing, although the budget is limited. An example of this is the current worldwide situation, due to the coronavirus pandemic, which has led to excessive public spending and reduced tax revenues.

Considering the Brazilian federalism model, Suzart, Zuccolotto and Rocha (2018) state that intergovernmental transfers, on average, reach $86 \%$ of total revenues in 4,203 Brazilian municipalities. Therefore, there is local dependence on government transfers that can generate risks of deficits in situations that lead central governments to reduce transfers. In any case, the theoretical view that public expenditures and revenues are balanced and, consequently, lead to a symmetrical behavior of costs between periods prevails. Despite the evidence, the asymmetry in the public cost behavior, by the cost stickiness approach, still lacks empirical evidence.

Based on this perspective, which still remains obscure in the public sector literature, the question-problem that guides this study is: how do costs behave in the local governments of Santa Catarina from the cost stickiness perspective? And, to answer this question, we aim to analyze the cost behavior in the local governments of Santa Catarina from the cost stickiness perspective.

Thus, based on the previously mentioned studies on the flypaper effect in the public sector, which suggest the existence of cost asymmetry based on a theoretical approach, taking only part of the revenue collected for analysis purposes, this study corrects some distortions of the statistical models used to adapt to the CST modeling. In this sense, we propose and run models that best fit the public sector's characteristics.

The study is justified by the relevance in identifying cost behavior in local governments, since the literature still lacks maturity. For Wu, Young, Yu, and Hsu (2020), the topic is current, and the scarce literature is an obstacle for studies on cost behavior in the public sector. Also, according to Hosomi and Nagasawa (2018), there is no proof of the cost stickiness phenomenon in the pure public sector. Therefore, this study's main contribution is to prove the cost stickiness phenomenon in the pure public sector, even when analyzed in account groups.

It is worth noting that the flypaper statistical method is specific to the public sector, while the cost stickiness behavior approach was initially developed based on business samples. Therefore, this study adapts the CST model to the public sector peculiarities, so that the essence of Anderson et al.'s (2003) perspective and the elements already contemplated in the literature are not mischaracterized.

\section{THEORETICAL BACKGROUND}

This study deals with the cost behavior topic, which considers the variation between revenues and total costs for different periods. In this sense, the approach on asymmetric cost behavior developed by Anderson et al. (2003), which gave rise to CST, assumes that costs increase when revenue increases, but do not decrease in the same proportion when there is a decrease in revenue (sticky cost). In other words, there is a "stickiness" that does not allow the variation in costs to follow the variation in revenues. It is worth pointing out that the reverse is also true (anti-sticky behavior). In short, the asymmetric effect from this perspective, in the international literature, is called cost stickiness.

The CST approach of Anderson et al. (2003) was replicated in companies in Brazil by Medeiros, Costa, and Silva (2005), who also evidenced the phenomenon. However, Richartz and Borgert (2020) contributed to the theory by identifying eleven factors that explain cost stickiness, 
as a function of business characteristics and their evolution over time. It is worth noting that the present study addresses CST applied to the public sector, while the literature, in general, focuses on private sector observations.

Adaptations of techniques, methods, and theories from other areas of knowledge, due to the diversity of concepts and distinct accounting processes in the sector, require a distinct perspective for application in the public sector (Suzart, 2012). We investigated the asymmetric effects of public spending regarding the economic phenomenon called the flypaper behavior or effect. In this way, we sought evidence that variations in transfers have the same or a proportionally different effect on expenditures than would be the case if private income varied by the same amount.

On research within the public sector, we measured asymmetry with a focus on the flypaper effect or behavior, which limits the findings to transfers received from another government sphere. For example, Gamkhar and Oates (1996) checked municipal and state expenditures in the United States in response to variations in government transfers. Volden (1999) analyzed health care spending in US states compared to the government transfers received, while Levaggi and Zanola (2003) analyzed the health care spending behavior as a function of transfer revenues in local governments in Italy. Meanwhile, Lago-Peñas (2008) studied asymmetric effects in Spanish municipalities on capital and current expenditures. Sakurai (2013) investigated asymmetric behavior in Brazilian municipalities, analyzing totals and separately by expenditure, and current and capital revenues. Gennari and Messina (2014) studied the same behavior in Italian local governments by total expenditure. Thus, Table 1 summarizes the commented studies and suggests the behavior found associating the flypaper effect with the cost stickiness effect.

Table 1

\section{Previous studies}

\begin{tabular}{|c|c|c|c|c|c|c|}
\hline Authors & Country & Year & Sample & Revenues & Expenditures & Suggested Behavior \\
\hline $\begin{array}{l}\text { Gamkhar and } \\
\text { Oates }\end{array}$ & USA & 1996 & $\begin{array}{c}\text { U.S. } \\
\text { municipalities } \\
\text { and states }\end{array}$ & Transfers & Totals & Symmetric \\
\hline Volden & USA & 1999 & $\begin{array}{l}\text { American } \\
\text { states }\end{array}$ & $\begin{array}{l}\text { Transfers } \\
\text { linked to } \\
\text { welfare } \\
\text { benefits }\end{array}$ & $\begin{array}{c}\text { Linked to welfare } \\
\text { benefits }\end{array}$ & Asymmetric \\
\hline $\begin{array}{l}\text { Anderson, } \\
\text { Banker, and } \\
\text { Janakiraman }\end{array}$ & USA & 2003 & $\begin{array}{l}\text { American } \\
\text { Companies }\end{array}$ & Totals & $\begin{array}{l}\text { Sales, general and } \\
\text { administrative }\end{array}$ & $\begin{array}{c}\text { Asymmetric (cost } \\
\text { sticky) }\end{array}$ \\
\hline $\begin{array}{l}\text { Levaggi and } \\
\text { Zanola }\end{array}$ & Italy & 2003 & $\begin{array}{l}\text { Italian Local } \\
\text { Governments }\end{array}$ & Transfers & $\begin{array}{l}\text { Totals and by } \\
\text { economic } \\
\text { category }\end{array}$ & Asymmetric \\
\hline $\begin{array}{l}\text { Medeiros, } \\
\text { Costa, and } \\
\text { Silva }\end{array}$ & Brazil & 2005 & $\begin{array}{c}\text { Brazilian } \\
\text { Companies }\end{array}$ & Totals & $\begin{array}{l}\text { Sales, general and } \\
\text { administrative }\end{array}$ & $\begin{array}{c}\text { Asymmetric (cost } \\
\text { sticky) }\end{array}$ \\
\hline Lago-Peñas & Spain & 2008 & $\begin{array}{c}\text { Spanish } \\
\text { Municipalities }\end{array}$ & Transfers & Totals & Asymmetric \\
\hline Sakurai & Brazil & 2013 & $\begin{array}{c}\text { Brazilian } \\
\text { municipalities }\end{array}$ & Transfers & $\begin{array}{l}\text { Total and by } \\
\text { specific } \\
\text { components }\end{array}$ & $\begin{array}{l}\text { Symmetric in total; } \\
\text { asymmetric in } \\
\text { specific components }\end{array}$ \\
\hline $\begin{array}{l}\text { Gennari and } \\
\text { Messina }\end{array}$ & Italy & 2014 & $\begin{array}{l}\text { Italian Local } \\
\text { Governments }\end{array}$ & Transfers & Totals & Symmetric \\
\hline $\begin{array}{l}\text { Hosomi and } \\
\text { Nagasawa }\end{array}$ & Japan & 2018 & $\begin{array}{l}\text { Local public } \\
\text { companies }\end{array}$ & $\begin{array}{l}\text { Operating } \\
\text { revenue } \\
\text { (public and }\end{array}$ & $\begin{array}{l}\text { Operating } \\
\text { expenses }\end{array}$ & $\begin{array}{l}\text { Asymmetric (cost } \\
\text { anti-sticky) }\end{array}$ \\
\hline
\end{tabular}




\begin{tabular}{|c|c|c|c|c|c|c|}
\hline & & & & private) & & \\
\hline $\begin{array}{l}\text { Richartz and } \\
\text { Borgert }\end{array}$ & Brazil & 2020 & $\begin{array}{l}\text { Brazilian } \\
\text { Companies }\end{array}$ & Totals & $\begin{array}{l}\text { Sales, general and } \\
\text { administrative }\end{array}$ & $\begin{array}{l}\text { Asymmetric (cost } \\
\text { sticky) }\end{array}$ \\
\hline
\end{tabular}

Source: Prepared by the authors (2021).

As we can see, in the public sector there is no consensus regarding the evidence of asymmetric effects in the cost behavior, mainly because, when analyzing total revenues and expenses, the behavior is symmetrical, due to the areas' normative framework, which establishes a balanced budget. Studies on specific government programs are limited to the flypaper effect, which limits the findings to the government actions chosen and the methods used. Only the study by Hosomi and Nagasawa (2018) applies CST when analyzing Japanese local public companies (private companies with government authorization and subsidy to provide public services). However, the authors report that these companies follow private accounting rules and that if they were purely public, it would not be possible to apply CST. Thus, the results so far found for cost behavior in the public sector are not conclusive and do not follow the CST approach.

\section{METHODOLOGICAL PROCEDURES}

We developed this study through regression analysis with panel data, based on a set of municipalities (cross-section) observed over time (time series). The population, which is the object of the study, is represented by the 295 municipalities of the state of Santa Catarina, located in southern Brazil, from 1999 to 2018, that is, referring to the last 20 years of published data. However, we highlight the absence of specific data for three municipalities: revenues and expenses for Flor do Sertão in 2012, Alfredo Wagner and Santo Amaro da Imperatriz in 2014. Furthermore, by 2012, Santa Catarina had 293 municipalities, and as of 2013, the municipalities of Balneário Rincão and Pescaria Brava were created.

We requested the data via the ombudsman system to the Santa Catarina State Court of Accounts (TCE/SC), which provided it. We manually collected some missing information from the public accounts portal of this same State Court. Aiming to minimize inflationary effects, we adjusted the data using the National Wide Consumer Price Index (IPCA), available on the Brazilian Institute of Geography and Statistics' (IBGE, 2019) website.

In the data's multivariate analysis, we followed the methodology proposed by Anderson et al. (2003) and adopted in Brazil by Medeiros et al. (2005) and Richartz and Borgert (2020), already consolidated in the literature. Although the model focuses on private firms, we chose to use it within the public sector, since previous studies focused on the public sector propose econometric models that analyze the behavior of expenditures only regarding government transfers (flypaper behavior).

For this study's purposes, we adapted the Anderson et al. (2003) model's costs, represented by the total costs and expenses appropriated in the accounting statement in the private sector, for the public sector, considering all the executed public budget expenses (settled in the period) as the model's costs.

However, we recognize the obvious differences between the public and private sectors, so we discussed the analysis of the results obtained in the public sphere. That said, we used the regression model to verify how public expenditures behave regarding variations in public revenues, with a description of the respective periods. Its specification is represented as:

$$
\left.\log \left\lceil\frac{\text { despesas }_{i, t}}{\text { despesas }_{i, t-1}}\right\rceil=\beta_{0}+\beta_{1} \log \left\lceil\frac{\text { receitas }_{i, t}}{\text { receitas }_{i, t-1}}\right\rceil+\beta_{2} \text { Dummy }_{i, t} * \log \mid \frac{\text { receitas }_{i, t}}{\text { receitas }_{i, t-1}}\right\rceil+\varepsilon_{i, t}
$$


Expenditures represent the dependent variable and revenues the independent ones, $i$ corresponds to each observed municipality, $t$ corresponds to each year, $t$ - 1 indicates the previous period, and $\varepsilon$ denotes the equation's error component. The dummy variable takes the value 1 when there is a drop in revenue between the previous year and the reference year (revenue ${ }_{\mathrm{i}, \mathrm{t}}<$

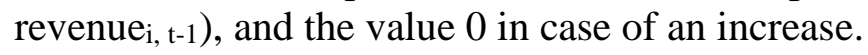

The coefficient $\beta_{1}$ measures the percentage increase in expenses compared to the $1 \%$ increase in revenues. In the case of revenue reduction, the dummy variable becomes part of the equation and, thus, the expenditure reduction percentage compared to the $1 \%$ decrease in revenue is measured by the sum of the coefficients $\beta_{1}$ and $\beta_{2}$. According to the model, in asymmetric expenditures, the variance with towards increasing revenues should be greater than the variance towards decreasing revenues, resulting in $\beta_{1}>0, \beta_{2}<0$ and $\beta_{1}+\beta_{2}<1$ (Medeiros et al., 2003).

The linear logarithmic specification fixes the effects of the distances between observed values, i.e., it increases the distances between small values and reduces the distances between large values (Barbetta, 2011). Thus, the variables' comparability among the municipalities becomes possible since the effects of size diversity among them are softened with the logarithmic transformation.

As for the regression models, the Breusch-Pagan, Chow's F, and Hausman's tests indicate the pooled regression as the most consistent estimator. Subsequently, we tested the models for autocorrelation, via the test proposed by Wooldridge, and heteroscedasticity by the Wald test, which were confirmed for the models. Although the graphical analysis indicated a homogeneous distribution in the residuals versus linear prediction graphic, we re-estimated the models with robust standard errors to make them more accurate. Furthermore, it is noteworthy that the normality tests rejected the null hypothesis of the residuals' normal distribution. However, considering the size of the analyzed sample, we assume asymptotic normality, supported by the central limit theorem (Gujarati, 2006).

As for the research procedures, we analyzed the variation in public expenditures according to the variation in public revenues. The calculation using total value is typical of CST, while the calculation using revenue groups is typical of flypaper. We investigated the asymmetry in two proposals, the first considering total expenditures and the second, component grouping.

Table 2

\section{Procedures for analyzing the behavior of total expenses compared to revenues}

\begin{tabular}{l|l}
\hline Analysis 1 & Asymmetric behavior of total expenses compared to total revenues. \\
\hline Analysis 2 & $\begin{array}{l}\text { Asymmetric behavior of total expenses compared to revenues by sources of resources (2.1 - } \\
\text { own revenues and } 2.2 \text { - government transfers). }\end{array}$ \\
\hline
\end{tabular}

Source: Prepared by the authors (2021).

The second proposal comprises the analysis of asymmetric behavior compared to functional classification expenses, motivated by the previous studies that brought evidence of asymmetry in public costs (Table 1). These expenses are established in MOG Ordinance No. 42, April 14, 1999, which had some classifications updated in 2012 (MOG Ordinance No. 42, 1999). According to this legal standard, the function is the highest level of aggregation of competence areas in the public sector.

In all, the functional account assignment specifies 28 functions. However, we observed that for the sample studied, certain functions represent less than $0.5 \%$ of the total expenses. In addition, we observed that some function descriptions presented modifications throughout the analyzed period. Thus, to make the analysis of spending behavior more representative, we grouped the functions into seven groups, according to their similarities. The group called "Other 
Functions" comprises the functions that represent less than $5 \%$ of the total expenses in the period.

Table 3

Grouping expenses in "Function Groups"

\begin{tabular}{|c|c|c|c|}
\hline Function & Group & Function & Group \\
\hline $\begin{array}{l}\text { Management } \\
\text { Management and Planning } \\
\text { Communications }\end{array}$ & $\begin{array}{l}\text { Management and } \\
\text { Communications }\end{array}$ & \multirow{2}{*}{$\begin{array}{l}\text { National Defense } \\
\text { National Defense and Public } \\
\text { Security } \\
\text { Public Security } \\
\text { Foreign Affairs } \\
\end{array}$} & \multirow{2}{*}{$\begin{array}{l}\text { National } \\
\text { Defense, } \\
\text { Public } \\
\text { Security, } \\
\text { and Foreign } \\
\text { Affairs }\end{array}$} \\
\hline $\begin{array}{l}\text { Assistance and Social Security } \\
\text { Social Assistance }\end{array}$ & \multirow{2}{*}{$\begin{array}{l}\text { Assistance and } \\
\text { Social Security }\end{array}$} & & \\
\hline $\begin{array}{l}\text { Social Security } \\
\text { Work }\end{array}$ & & \multirow{4}{*}{$\begin{array}{l}\text { Agriculture } \\
\text { Agrarian Organization } \\
\text { Environmental Management } \\
\text { Energy } \\
\text { Energy and Mineral Resources } \\
\text { Citizenship Rights } \\
\text { Special Charges } \\
\text { Essential to Justice } \\
\text { Fundef } \\
\text { Industry } \\
\text { Industry, Commerce, and Services } \\
\text { Judiciary } \\
\text { Legislative } \\
\text { Contingency Reserve }\end{array}$} & \multirow{4}{*}{$\begin{array}{c}\text { Other } \\
\text { Functions }\end{array}$} \\
\hline $\begin{array}{l}\text { Education } \\
\text { Culture } \\
\text { Education and Culture } \\
\text { Science and Technology } \\
\text { Sports and Leisure } \\
\end{array}$ & $\begin{array}{l}\text { Education and } \\
\text { Culture }\end{array}$ & & \\
\hline $\begin{array}{l}\text { Health } \\
\text { Health and Sanitation } \\
\text { Sanitation } \\
\end{array}$ & $\begin{array}{l}\text { Health and } \\
\text { Sanitation }\end{array}$ & & \\
\hline $\begin{array}{l}\text { Housing } \\
\text { Housing and Urbanism } \\
\text { Transportation } \\
\text { Urbanism } \\
\text { Regional Development } \\
\text { Commerce and Services }\end{array}$ & $\begin{array}{c}\text { Housing, } \\
\text { Transportation, } \\
\text { Urbanism, } \\
\text { Commerce, and } \\
\text { Services }\end{array}$ & & \\
\hline
\end{tabular}

Source: Prepared by the authors (2021).

Sakurai (2013) performed a similar procedure for grouping expenses, breaking them down into current, investment, and social expenses. In this sense, one of this study's contributions can be understood as the analysis of the data broken down into the specified classes of expenses and revenues, grouped into distinct categories. The use of partial revenue, for greater representativeness of the results, is something typical of flypaper phenomenon analyses, which is used for the public sector. In this study, we adapted the CST formula by using parts of public expenditures to represent costs. Thus, we presented the procedure for analyzing the behavior of expenses by function group as a third proposal, as shown in Table 4.

Table 4

Procedures for analyzing the behavior of expenses compared to revenues after grouping the Functions

\begin{tabular}{l|l}
\hline Analysis & Asymmetric behavior of expenses by Function Groups compared to total revenues. \\
\hline
\end{tabular}

Source: Prepared by the authors (2021).

In total, we estimated nine regressions based on the model presented. It is noteworthy that, for all the estimations, we performed the tests above mentioned. Thus, the best model pointed out was the pooled regression for all the estimated regressions. Next, we present the results and considerations regarding the municipalities of Santa Catarina and the behavior of public spending in the period. 


\section{RESULTS}

In the analyzed 20-year period (1999-2018), there was growth in both revenues and expenses (in the order of $348 \%$ ), as was to be expected, since population and economic growth is also assumed in the period. Own revenues increased by $498 \%$, while transfer revenues grew by $289 \%$, which reveals, if compared to the flypaper study by Sakurai (2013), a lower percentage of dependence on the Union and state, in the revenues of municipalities.

As for the Function Groups (Figure 1), as specified above, you can see that some groups are more representative than others. The group that involves expenses with National Defense, Public Security, and Foreign Affairs had no expenses registered, since they are not typical municipal expenses. The representativeness of revenues and expenditures, within the executed public budget, is already enough to realize that asymmetry based, only on transfer revenues (Gamkhar \& Oates, 1996; Volden, 1999; Levaggi \& Zanola, 2003; Lago-Peñas, 2008; Sakurai, 2013; Gennari \& Messina, 2014), can distort the statistical model of Anderson et al. (2003), as it considers the totals.

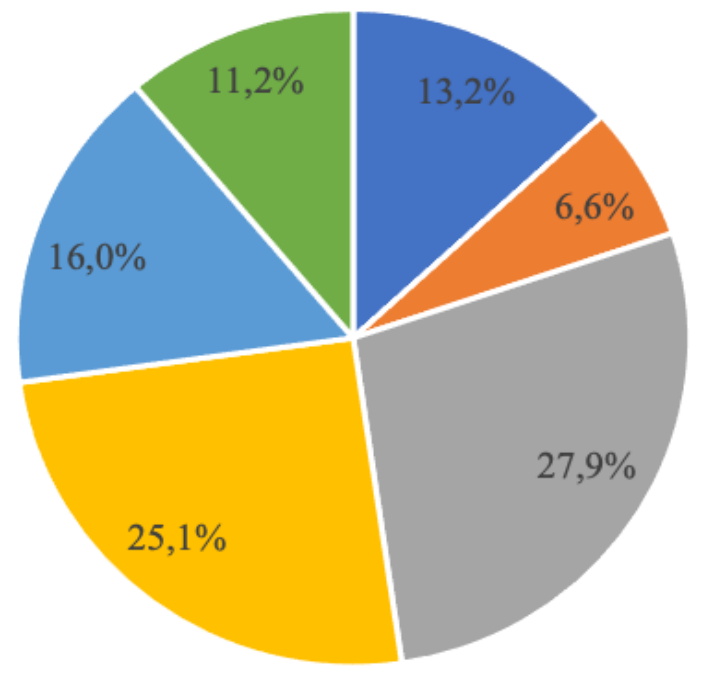

- Admin istração e Comunicações

- Assistência e Previdência Social

- Educação e Cultura

- Saúde e Saneamento

- Habitação, Transporte, Urbanismo, Comércio e Serviços

- Demais Funções

Figure 1. Spend by Function Group in Relation to Total Spend

Source: Prepared by the authors (2021).

Table 5 presents the statistics of the regression model estimations, whose research results we obtained as defined in the methodological procedures. The coefficients $\beta_{0}, \beta_{1}$, and $\beta_{2}$, the results of the Wald chi ${ }^{2}$ statistics, the $\mathrm{R}^{2}$ correlation coefficients, and the number of observations are presented. Analyses 1 and 2 correspond, respectively, to the variations in total expenses compared to the variations in total revenue (1), own revenue (2.1), and government transfers (2.2).

Table 5

Estimated Coefficients of Variation for Analyses 1 and 2

\begin{tabular}{l|c|c|c}
\hline Results & Analysis 1 & Analysis 2.1 & Analysis 2.2 \\
\hline Parameter $\beta_{0}$ & 0.0096 & 0.0188 & 0.013 \\
Standard Error & 0.0006 & 0.0007 & 0.0010 \\
$z$-statistic & 15.64 & 26.84 & 13.13 \\
P $|z|$ & $0.0000^{* * *}$ & $0.0000^{* * *}$ & $0.0000^{* * *}$ \\
\hline Parameter $\beta_{1}$ & $\mathbf{0 . 4 4 4 2}$ & $\mathbf{0 . 0 7 4 3}$ & $\mathbf{0 . 4 3 8 4}$ \\
Robust Standard Errors & 0.0130 & 0.0059 & 0.0159 \\
\hline
\end{tabular}




\begin{tabular}{l|c|c|c}
\hline$z$-statistic & 34.15 & 12.55 & 27.60 \\
$\mathrm{P}>|z|$ & $0.0000^{* * *}$ & $0.0000^{* * *}$ & $0.0000^{* * *}$ \\
\hline Parameter $\beta_{2}$ & $\mathbf{( 0 , 2 9 7 3 )}$ & $\mathbf{( 0 , 0 5 2 3 )}$ & $\mathbf{( 0 , 1 3 4 1 )}$ \\
Robust Standard Errors & 0.0311 & 0.0087 & 0.0325 \\
$z$-statistic & $(9,57)$ & $(6,01)$ & $(4,12)$ \\
$\mathrm{P}>|z|$ & $0.0000^{* * *}$ & $0.0000^{* * *}$ & $0.0000^{* * *}$ \\
\hline$\beta_{1}+\beta_{2}$ & $\mathbf{0 . 1 4 6 8}$ & $\mathbf{0 . 0 2 2 0}$ & $\mathbf{0 . 3 0 4 3}$ \\
\hline $\mathrm{R}^{2}$ & 0.1783 & 0.0427 & 0.1824 \\
Wald chi $^{2}$ & $1,173.42$ & 159.89 & 206.34 \\
Prob $>$ chi $^{2}$ & 0.0000 & 0.0000 & 0.0000 \\
Observations (no.) & 5,576 & 5,576 & 5,576 \\
Municipalities (no.) & \multicolumn{3}{|c}{} \\
\cline { 2 - 4 }
\end{tabular}

Note. $* * *$ denotes statistical significance at $1 \%$.

Source: Prepared by the authors (2021).

As predicted by the model of Anderson et al. (2003), we find that the signs of the coefficients indicate asymmetry $\left(\beta_{1}>0, \beta_{2}<0\right.$, and $\left.\beta_{1}+\beta_{2}<1\right)$. Thus, we can say that the proportion of the increase in expenses due to an increase in revenues is greater than the proportion of the decrease in expenses due to an equivalent decrease in revenues. In other words, in case of a reduction in public revenues, expenditures do not reduce in the same proportion as they increase in case of an increase in the same revenues. The statistics were significant at $1 \%$ for all four analyses.

In analysis 1 , which indicates variation of total expenses compared to total revenues, the coefficient $\beta_{1}$ presented a value of 0.4442 . Therefore, total expenses increased by $0.4442 \%$ compared to the $1 \%$ increase in total revenues. Adding $\beta_{1}$ with $\beta_{2}$ results in 0.1468 , as shown in Table 5. Thus, expenses decreased by $0.1468 \%$ compared to the $1 \%$ decrease in total revenues. We can observe that the variation was asymmetrical, since the reduction in municipal expenses did not accompany, in the same proportion, the decrease in revenues.

Analyses 2.1 and 2.2, which investigated the behavior of total expenditures compared to own revenues and government transfers, demonstrated that the asymmetric effect is also confirmed when revenues are analyzed by source of funds. In the case of transfers (analysis 2.2), each $1 \%$ increase led to an increase of $0.4384 \%$ in expenses, while the reduction in the same proportion only decreased these expenses by $0.3043 \%$. Considering the dependence that municipalities still have on transfers from the Union and the states, moments of economic downturns and, consequently, a reduction in fundraising, can lead public entities to budgetary imbalance, since the reduction in their cost and expenditure structure cannot match the decrease in revenues.

Therefore, the analysis of the cost behavior mediated by revenue variation can be useful for municipal managers, as a way to understand the importance of the public budget as a management tool that, if well planned and executed, can still predict future revenue reductions and adapt public spending to such situations, thus avoiding austerity policies. Furthermore, society can also benefit from such analysis, either directly or indirectly, as a way to verify the efficient use of public resources.

In parallel to the costs stickiness approach, the results corroborate studies on flypaper by Volden (1999), Levaggi and Zanola (2003), and Lago-Peñas (2008), who found asymmetric impact of government transfers on spending in US states, Italian and Spanish local governments, successively. In turn, Gamkhar and Oates (1996), Gennari and Messina (2014), and Sakurai (2013) did not obtain sufficient evidence to confirm asymmetry in flypaper behavior in US states, Italian and Brazilian local governments. 
Table 6 presents the statistics of the regression model estimations, whose research results we obtained as defined in the methodological procedures. Analysis 3 corresponds to the variations by expenditure group compared to the variations in total revenues.

Table 6

Estimated Coefficients of Variation for Analysis 3 - Function Groups

\begin{tabular}{|c|c|c|c|c|c|c|}
\hline Results & Group 1 & Group 2 & Group 3 & Group 4 & Group 5 & Group 6 \\
\hline Parameter $\beta_{0}$ & 0.0019 & 0.0209 & 0.0010 & 0.0287 & $(0,0090)$ & 0.0254 \\
\hline Standard Error & 0.0018 & 0.0030 & 0.0038 & 0.0030 & 0.0023 & 0.016 \\
\hline$z$-statistic & 1.09 & 7.08 & 0.26 & 9.49 & 3.86 & 16.24 \\
\hline $\mathrm{P}>|z|$ & 0.2770 & $0.0000 * * *$ & 0.7930 & $0.0000 * * *$ & $0.0000 * * *$ & $0.0000 * * *$ \\
\hline Parameter $\beta_{1}$ & 0.2509 & 0.4038 & 0.5356 & 0.5385 & 0.8168 & 0.1158 \\
\hline Robust Standard Errors & 0.0390 & 0.0523 & 0.1176 & 0.0635 & 0.0477 & 0.0300 \\
\hline z-statistic & 6.43 & 7.71 & 4.56 & 8.48 & 17.11 & 3.86 \\
\hline $\mathrm{P}>|z|$ & $0.0000 * * *$ & $0.0000 * * *$ & $0.0000 * * *$ & $0.0000 * * *$ & $0.0000 * * *$ & $0.0000 * * *$ \\
\hline Parameter $\beta_{2}$ & $(0.2899)$ & $(0.4831)$ & $(0.5014)$ & $(0.3825)$ & $(0.4136)$ & 0.0337 \\
\hline Robust Standard Errors & 0.0591 & 0.1066 & 0.0795 & 0.1154 & 0.1115 & 0.0634 \\
\hline$z$-statistic & $(4.91)$ & $(4.53)$ & $(6.31)$ & $(3.32)$ & $(3.71)$ & 0.53 \\
\hline $\mathrm{P}>|z|$ & $0.0000 * * *$ & $0.0000 * * *$ & $0.0000 * * *$ & $0.0010 * * *$ & $0.0000 * * *$ & 0.5950 \\
\hline$\beta_{1}+\beta_{2}$ & $(0.0390)$ & $(0.0793)$ & 0.0342 & 0.1560 & 0.4032 & 0.1495 \\
\hline $\mathrm{R}^{2}$ & 0.0077 & 0.0084 & 0.0123 & 0.0122 & 0.0527 & 0.0047 \\
\hline Wald chi ${ }^{2}$ & 41.45 & 59.50 & 48.52 & 88.93 & 294.73 & 26.51 \\
\hline Prob $>$ chi $^{2}$ & 0.0000 & 0.0000 & 0.0000 & 0.0000 & 0.0000 & 0.0000 \\
\hline Observations (no.) & 5,556 & 5,432 & 5,576 & 5,516 & 5,564 & 5,576 \\
\hline Municipalities (no.) & \multicolumn{6}{|c|}{295} \\
\hline
\end{tabular}

Note. Parameter values rounded to four decimal places. *** denotes statistical significance at $1 \%$.

Source: Prepared by the authors (2021).

It is noteworthy, in Table 6, that the number of observations was reduced when analyzing the expenses by Function Groups. Since in the public sector accounting is different from the private sector, we have grouped function accounts here to resemble cost stickiness studies that analyze diverse types of cost accounts (typical of private sector accounting), following the flypaper's grouping logic, which is by similarity of public revenue source. It happened because some municipalities did not present expenses inherent to certain groups in some periods. When verifying the behavior of expenses by groups compared to total revenues, we observe that the statistics were not so significant, if compared to the analyses in Table 5, possibly because of the balanced budget imposition for the public sector.

For Groups 1 (management and communications) and 2 (assistance and social security), the coefficients indicate asymmetric behavior, i.e., expenditures increased by $0.2509 \%$ and $0.4038 \%$, respectively, when total revenues increased by $1 \%$. However, in these groups, expenses continued to increase by $0.0390 \%$ and $0.0793 \%$, when revenues decreased by $1 \%$.

In Group 3 (education and culture), we can see that for $1 \%$ growth in total revenues, expenditures increased by $0.5356 \%$, but reduced by only $0.0342 \%$ if revenues decreased by the same proportion. Such results support the proposition present in the literature that spending in this category cannot be so easily reduced, given its social function (Sakurai, 2013). We can observe that municipal spending data for this group (Figure 1) amounts to $27.85 \%$ of total spending between 1999 and 2018.

Similarly, Group 4 (health and sanitation) also presented a significant increase in expenses $(0.5385 \%)$ upon a $1 \%$ increase in revenues, as well as a decrease in expenses $(0.1560 \%)$ upon a $1 \%$ decrease in revenues. This group represents $25.14 \%$ of all municipal spending in the analyzed period. Thus, groups 3 and 4 make up more than $50 \%$ of total municipal expenses. 
Group 5 (housing, transportation, urban development, commerce, and services) presented a significant increase of $0.8168 \%$ for every $1 \%$ increase in total revenues and decreased $0.4032 \%$ when total revenues decreased.

Finally, as for Group 7 (national defense, public security, and foreign affairs), we noted that the $\beta_{2}$ coefficient was positive. Therefore, we cannot say that the variation of expenses as a function of revenues is asymmetric based on the model adopted. In addition, the $p$-value for $\beta_{2}$ was above the significance level adopted in this study. Thus, there is not enough evidence to confirm asymmetric behavior in this group.

Table 7 presents a result summary of the three analyses performed, according to the methodological procedures described, highlighting the cost effect, according to the cost stickiness approach.

Table 7

Cost behavior in municipalities of Santa Catarina (1999 to 2018) based on the CST

\begin{tabular}{c|c|c|c|c}
\hline Expenditures & Revenues & $\begin{array}{c}\text { For every 1\% } \\
\text { increase in } \\
\text { revenue, } \\
\text { spending } \\
\text { increases }\end{array}$ & $\begin{array}{c}\text { For every 1\% } \\
\text { decrease in } \\
\text { revenue, } \\
\text { spending } \\
\text { decreases }\end{array}$ & Effect \\
\hline Totals & Totals & $0.4442 \%$ & $0.1468 \%$ & $\begin{array}{c}\text { Asymmetric } \\
\text { (sticky costs) }\end{array}$ \\
\hline Totals & Own & $0.0743 \%$ & $0.0220 \%$ & $\begin{array}{c}\text { Asymmetric } \\
\text { (sticky costs) }\end{array}$ \\
\hline Totals & Transfers & $0.4384 \%$ & $0.3043 \%$ & $\begin{array}{c}\text { Asymmetric } \\
\text { (sticky costs) }\end{array}$ \\
\hline Management and Communications & Totals & $0.2191 \%$ & $0.0636 \%$ & $\begin{array}{c}\text { Asymmetric } \\
\text { (sticky costs) }\end{array}$ \\
\hline Assistance and Social Security & Totals & $0.3930 \%$ & $0.0492 \%$ & $\begin{array}{c}\text { Asymmetric } \\
\text { (sticky costs) }\end{array}$ \\
\hline Education, Culture, Sports, and Leisure & Totals & $0.5356 \%$ & $0.0342 \%$ & $\begin{array}{c}\text { Asymmetric } \\
\text { (sticky costs) }\end{array}$ \\
\hline Health and Sanitation & Totals & $0.5385 \%$ & $0.1560 \%$ & $\begin{array}{c}\text { Asymmetric } \\
\text { (sticky costs) }\end{array}$ \\
\hline Housing, Transportation, Urbanism, & Totals & $0.8168 \%$ & $0.4032 \%$ & $\begin{array}{c}\text { Asymmetric } \\
\text { (sticky costs) }\end{array}$ \\
\hline Commerce, and Services & Totals & $0.1158 \%$ & $0.1495 \%$ & Inconclusive \\
\hline Other Functions & & &
\end{tabular}

Source: Prepared by the authors (2021).

Therefore, we found that the behavior of expenses compared to revenues was asymmetric and sticky in eight of the nine models run. However, the $\mathrm{R}^{2}$ coefficient values indicate the existence of other factors not included in the developed model, which can explain this behavior. In this sense, future studies can investigate these factors and verify their influence on public spending in various places and contexts.

\section{FINAL CONSIDERATIONS}

In this study, we performed three separate analyses by adapting the CST statistical model by Anderson et al. (2003), for the public sector. The basis of the adaptations were account groupings, following the flypaper phenomenon logic. Of the nine models we tested, eight confirmed the sticky cost phenomenon, which contributes to the CST that, until then, commonly presented tests in private sector samples. In this sense, we can answer the study problem, from the cost stickiness perspective, with the statement that the cost behavior in the local governments 
of Santa Catarina are predominantly sticky costs. This means that the cost groupings analyzed do not decrease compared to revenue in the same proportion as they increase.

It is worth noting that in the public sector there is a similar phenomenon, called flypaper, which uses a reduced share of revenue to measure cost asymmetry. For this reason and in an attempt to associate flypaper with the cost stickiness phenomenon, to adapt CST's cost behavior calculation methodology, we performed tests on diverse groups of revenue and cost accounts. Therefore, this study's results should be analyzed with the weighting that the CST formula, proposed by Anderson et al. (2003), has been adapted.

The results of analysis three (by function groups) were not as significant as the others and need to be reviewed. Therefore, for future research, spending functions should be analyzed separately and thus identify factors that lead to cost stickiness in each area of public sector performance. The diversity of activities involving governments, and the non-profit character, transcends the explanations of this phenomenon so far available in the CST literature.

Thus, the results are of interest to managers and researchers who aim to improve efficiency in public spending. Identifying the costs that do not behave symmetrically can aid planning and make it possible to readjust more efficiently over time. In the public sector, the focus is on balance, not profit, perhaps this is a limitation not considered in this study and that requires a different and deeper look, since public finances have peculiarities that need to be considered.

As the study's limitations, we highlight the adaptations of concepts that were initially developed for the corporate environment, the adaptation of the formula that considered the account grouping for greater representativeness of the results, the incipient literature on the cost stickiness behavior in the public area, and the analysis restriction to the budget execution of the municipalities of Santa Catarina. Another important consideration, which we did not explore in depth in this study, is the fact that the public sector is not focused on profit, so the results tend to be balanced, as defined in the accounting standards specific to governments.

Cost behavior in the public sector, considering the new CST approach, is a research gap that needs to be explored. However, the different nomenclatures of accounting accounts can lead to errors in the adaptation of private models for the public sector, so standardization of accounting concepts and terms is important. In summary, the term costs is used internationally as a synonym for the total expenditures recorded in the period, when the approach is about cost stickiness, so public costs correspond to the executed budget expenditures, as we used in this study.

Finally, it is worth pointing out that, due to the public sector's peculiarities, we can consider cost behavior from the perspective of other theories developed for the sector itself, since it is not possible to transpose private sector techniques without making the necessary adaptations to the public sector.

\section{REFERENCES}

Anderson, M. C., Banker, R. D., \& Janakiraman, S. N. (2003). Are selling, general, and administrative costs "sticky"? Journal of accounting research, 41(1), 47-63. https://doi.org/10.1111/1475-679X.00095

Barbetta, P.A. (2011). Estatística aplicada às Ciências Sociais. (7a. ed.) Florianópolis: UFSC.

Bracci, E., Humphrey, C., Moll, J., \& Steccolini, I. (2015). Public sector accounting, accountability and austerity: more than balancing the books? Accounting, Auditing \& Accountability Journal, 28(6), 878-908. https://doi.org/10.1108/AAAJ-06-2015-2090 
Gamkhar, S., \& Oates, W. (1996). Asymmetries in the response to increases and decreases in intergovernmental grants: some empirical findings. National tax journal, 49(4), 501-512.

Gennari, E., \& Messina, G. (2014). How sticky are local expenditures in Italy? Assessing the relevance of the "flypaper effect" through municipal data. International tax and public finance, 21(2), 324 -344. https://doi.org/10.1007/s10797-013-9269-9

Gujarati, D. (2006). Econometria Básica. (4a. ed.) Rio de Janeiro: Elsevier.

Helden, J. V., \& Uddin, S. (2016). Public sector management accounting in emerging economies: a literature review. Critical Perspectives on Accounting, 41, 34-62. https://doi.org/10.1016/j.cpa.2016.01.001

Hosomi, S., \& Nagasawa, S. (2018). Empirical study on asymmetric cost behavior: analysis of the sticky costs of local public enterprises. Asia-Pacific Management Accounting Journal (APMAJ), 13(2), 55-82.

Instituto Brasileiro de Geografia e Estatística (IBGE). (2019). Sistema Nacional de índices de Preço ao Consumidor. Índice Nacional de Preços ao Consumidor Amplo - IPCA e Índice Nacional de Preços ao Consumidor - INPC. Recuperado de https://sidra.ibge.gov.br/pesquisa/snipc.

Kandil, M. (2001). Asymmetry in the effects of US government spending shocks: Evidence and implications. The Quarterly Review of Economics and Finance, 41(2), 137-165. https://doi.org/10.1016/S1062-9769(00)00066-1

Lago-Penãs, S. (2008). Local governments asymmetric reactions to grants: causes and $\begin{array}{llll}\text { consequences. Public } \quad \text { Finance } & \text { 219-235. }\end{array}$ https://doi.org/10.1177/1091142107299596

Levaggi, R., \& Zanolla, R. (2003). Flypaper effect and sluggishness: evidence from regional health expenditure in Italy. International Tax and Public Finance, 10, 535-547. https://doi.org/10.1023/A:1026118222901.

Medeiros, O. R., Costa, P. S., \& Silva, C. A. T. (2005). Testes empíricos sobre o comportamento assimétrico dos custos nas empresas brasileiras. Revista Contabilidade e Finanças, 16(38), 47-56. https://doi.org/10.1590/S1519-70772005000200005

Portaria MOG $n^{\circ}$ 42, de 14 de abril de 1999 (1999). Atualiza a discriminação da despesa por funções de que tratam o inciso I, do $\S 1^{\circ}$, do artigo $2^{\circ}$, e $\S 2^{\circ}$, do artigo $8^{\circ}$, ambos da Lei $n^{\circ}$ 4.320, de 17 de março de 1964; estabelece os conceitos de função, subfunção, programa, projeto, atividade, operações especiais, e dá outras providências. Brasília, DF. Recuperado de https://www.legisweb.com.br/legislacao/?id=182092

Richartz, F., \& Borgert, A. (2020). Fatores explicativos para o comportamento assimétrico dos custos das empresas listadas na B3. Revista Universo Contábil, 16 (3). https://doi:10.4270/ruc20203XX 
Sakurai, S. N. (2013). Efeitos assimétricos das transferências governamentais sobre os gastos públicos locais: evidências em painel para os municípios brasileiros. Pesquisa e Planejamento Econômico, 43(2), 309-332.

Santos, R. S., Ribeiro, E. M., Ribeiro, M. M., \& Pinto, F. L. B. (2017). Administração política e políticas públicas: em busca de uma nova abordagem teórico-metodológica para a (re)interpretação das relações sociais de produção, circulação e distribuição. Cadernos EBAPE.BR, 15(4), 939-959. http://dx.doi.org/10.1590/1679-395155017.

Suzart, J. A. S. (2012). Sistema federal brasileiro de custos: uma análise comparativa à luz das recomendações da IFAC. Revista de Gestão, Finanças e Contabilidade, 2(3), 39-55.

Suzart, J. A. S., Zuccolotto, R., \& Rocha, D.G. (2018). Federalismo fiscal e as transferências intergovernamentais: um estudo exploratório com os municípios brasileiros. Advances in Scientific and Applied Accounting, 11(1), 127-145. http://dx.doi.org/10.14392/asaa.2018110107

Volden, C. (1999). Asymmetric effects of intergovernmental grants: analysis and implications for U.S. welfare policy. Publius: the journal of federalism, 29(3), 51-73. https://doi.org/10.1093/oxfordjournals.pubjof.a030037

Wu, T. C., Young, C., Yu, C. \& Hsu, H. (2020). Are governmental expenditures also sticky? Evidence from the operating expenditures of public schools. Applied Economics, 52(16), 1763-1776. https://doi.org/10.1080/00036846.2019.1678731 